\author{
락토페린을 첨가한 저지방/저염 소시지의 품질 및 Escherichia coli \\ O157:H7에 대한 항균활성에 미치는 효과 \\ 이홍철 - 진구복 \\ 전남대학교 동물자원학부 및 농업과학기술연구소
}

\title{
Product Quality of Low-fat / salt Sausages Containing Lactoferrin and Antimicrobial Activity Against Escherichia coli O157:H7
}

\author{
H. C. Lee and K. B. Chin \\ Department of Animal Science and Institute of Agricultural Science and Technology, \\ Chonnam National University, Gwangju, 500-757 Korea
}

\begin{abstract}
This study was performed to determine potential antimicrobial activity of lactoferrin, which incorporated into the low-fat/salt sausages during storage either at 30 or $4^{\circ} \mathrm{C}$. First, the model study on the antimicrobial activity of lactoferrin was performed. Based on the model study, more than $0.25 \%$ of lactoferrin was required to have a distinctive antimicrobial activity for the growth of E. coli O157:H7 in the broth. However, extended shelf-life was not shown in the low-fat/salt sausages manufactured with lactoferrin during refrigerated storage. In addition, no synergistic effects of lactoferrin with sodium lactate were observed in the sausages. These results indicated that the addition of lactoferrin into the low-fat sausages did not have antimicrobial activity of E. coli O157:H7, due to the denaturation of lactoferrin or the complexity of the sausage, even though it had a distinctive antimicrobial effect in the model study.
\end{abstract}

(Key words : Lactoferrin, Antimicrobial activity, Low-fat/salt sausages, E. coli O157:H7, Sodium lactate)

\section{I. 서 론}

식육제품에 첨가되는 보존제나 방부제는 저 장기간 동안 병원성 미생물의 오염으로 인한 제 품의 부패를 막아 품질을 유지하는 역할을 한다. 특히, 식육가공품에 첨가되는 보존제는 병원성 미생물로 인해 오염된 가공품을 섭취하는 소비 자의 건강상 위해를 방지할 수 있다. 실제로 식 육가공품의 저장성을 증진하기 위해 사용되어지

\begin{abstract}
는 보존제로는 소르빈산(Sorbic acid, $\mathrm{C}_{6} \mathrm{H}_{8} \mathrm{O}_{2}$ ), 소르빈산 칼륨(Potassium sorbate, $\mathrm{C}_{6} \mathrm{H}_{7} \mathrm{O}_{2} \mathrm{~K}$ ), 안 식향산 나트륨 (Sodium benzoate, $\mathrm{C}_{7} \mathrm{H}_{5} \mathrm{O}_{2} \mathrm{Na}$ ) 등 이 있고, 유통기한 동안 제품의 품질을 유지하 는 역할을 한다. 하지만 화학보존료는 허용기 준량이 있어서 이를 초과할 경우 부작용을 초 래할 수 있으므로 보존료가 첨가된 식육가공품 을 과량 섭취할 경우 소비자의 건강을 위해할 수 있다. 이러한 이유로 천연물질로부터 유래
\end{abstract}

Corresponding author : Koo Bok Chin, Department of Animal Science, Chonnam National University, PukGwangju, P.O. Box 205, Gwangju, Korea 500-600,

Tel : 062-530-2121, Fax : 062-530-2129, e-mail : kbchin@chonnam.ac.kr 
한 항균제가 대안으로 부각되고 있으며, 천연 물질 유래의 키토산, 젖산나트륨, 자몽종자추출 물, 락토페린, 마늘 등의 항균효과가 보고되었다 (De Wit와 Rombouts, 1990; Jo 등, 2002; Farnaud 와 Evans, 2003; Benkeblia, 2004; Cvetnic 과 Vladimir-Knezevic, 2004; Qin 등, 2006). 또한 실제로 식육 및 식육제품에 응용 및 첨가되어 저장성을 증진시키고 품질을 유지한다고 이전 연 구에서 보고되었다(Darmadji와 Izumimoto, 1994; Kim 등, 1996; Lemay 등, 2002; Naidu, 2002; Sallam 등, 2004).

락토페린은 우유, 눈물, 혈액, 타액 등 수많 은 체액 분비장소에서 나오는 transferrin 계통의 철 이온 결합 당단백질이다. 락토페린은 체내 다양한 분비장소에서 분비되어 외부로부터 침 입하는 병원성미생물에 방어하는 기능을 한다. 이러한 락토페린은 많은 식품에 첨가되어 식품 시장에서 기능성 식품의 첨가물로 인정되고 있 으며, 최근에는 락토페린에 대한 응용연구가 활발히 진행되고 있다(DMV, 2001). 이러한 항 균활성 외에도 면역기능, 항산화, 항바이러스 기 능이 밝혀졌고, 이로 인해 기능성 식품 제조를 위해 그 응용범위가 확대되고 있다. 이미 특수 사료 개발에 첨가되었고(Kumari 등, 2003), 제조 분유 및 유제품에도 첨가되고 있다고 보고되었 다(Jovani 등, 2003). 더욱이 최근에는 그 응용범 위가 확대되어 식육제품에도 부분적으로 사용 가능성을 보이고 있다. 특히 식육에 있어서 병
원성 미생물의 오염과 성장을 억제함으로써 안 전성을 증가시키기 위하여 활성화된 락토페린 이 개발되어 사용되고 있고, 식품 및 식육에 응용되어 외부로부터 오염되는 미생물을 차단 하는 역할을 한다(Naidu, 2002). 실제로 쇠고기 스테이크와 Ready-to-eat(RTE) bologna 타입 육제 품에 처리한 락토페린이 접종된 Escherichia coli O157:H7와 Listeria monocytogenes에 저장 중 각 각 1.4-2.4, 6.3-6.4 $\log \mathrm{CFU} / \mathrm{cm}^{2}$ 로 억제됨이 보고되었다(Ransom과 Belk, 2003).

이러한 연구결과들을 기초로 하여 본 연구는 영양배지를 통한 모델연구와 저지방/저염 소시 지에 병원성 미생물인 E. coli O157:H7을 접종 하여, 락토페린의 항균능력을 평가하고, 이를 통해 락토페린의 항균활성과 식육제품에 첨가 한 락토페린의 천연보존료로써의 가능성을 확 인하기 위하여 실시하였다. 또한 기존에 저장 성 증진효과가 있다고 보고 된 천연의 젖산나 트륨과 복합첨가를 통한 상승효과가 나타나는 지를 확인하기 위해 수행하였다.

\section{ㅍ. 재료 및 방법}

\section{1. 소시지의 제조 및 품질검사}

(1) 실험설계

본 실험은 두 가지로 나누어 3번 반복 실험 하였다. 실험 1 에서는 락토페린을 첨가한 배지

Table 1. The formulation of low-fat sausages with lactoferrin (experiment 2-1)

\begin{tabular}{lcccc}
\hline & CTL $^{*}$ & \multicolumn{3}{c}{ Level of LN(\%) } \\
\cline { 3 - 5 } Ingredients & & 0.05 & 0.1 & 0.2 \\
\hline \hline Pork lean & 55 & 55 & 55 & 55 \\
Ice Water & 34 & 34 & 34 & 34 \\
Non-meat ingredients & 10 & 10 & 10 & 10 \\
\hline Whey Protein (WP, \%) & 1.0 & 1.0 & 1.0 & 1.0 \\
Lactoferrin (LN, \%) & 0.0 & 0.05 & 0.10 & 0.20 \\
\hline Total (\%) & 100 & 100.05 & 100.1 & 100.2 \\
\hline
\end{tabular}

*Treatments : CTL, low-fat sausage without lactoferrin(LN); LN 0.05\%, LN 0.1\%, LN 0.2\%. 
Table 2. The formulation of low-fat sausages with lactoferrin and sodium lactate (experiment 2-2)

\begin{tabular}{lcccccccc}
\hline \multirow{2}{*}{ Ingredients } & \multicolumn{3}{c}{ CTL } & & \multicolumn{3}{c}{ TRT (Sodium Lactate 2.0\%) } \\
\cline { 2 - 3 } \cline { 8 - 10 } & RFC $^{*}$ & LFC & & LS0 & LS1 & LS2 & LS3 \\
\hline \hline Pork lean/fat & $55 / 20$ & 55 & & 55 & 55 & 55 & 55 \\
Ice water & 18.1 & 35.6 & & 35.6 & 35.6 & 35.6 & 35.6 \\
Non-meat ingredients & 6.9 & 9.4 & 9.4 & 9.4 & 9.4 & 9.4 \\
\hline Lactoferrin (LN, \%) & 0 & 0 & & 0 & 0.3 & 0.6 & 0.9 \\
Sodium Lactate (SL, \%) & 0 & 0 & & 2 & 2 & 2 & 2 \\
\hline Total (\%) & 100 & 100 & & 102 & 102.3 & 102.6 & 102.9 \\
\hline
\end{tabular}

*Treatments: RFC, regular-fat control(fat, 20\%; salt, 1.0\%); LFC, low-fat control(salt, $1.0 \%$; LS0= sodium lactate(SL) $2.0 \%$ only; LS1= SL $2.0 \%$ +lactoferrin(LN) $0.3 \%$; LS2= SL $2.0 \%+\mathrm{LN} \quad 0.6 \%$; LS3 $=$ SL $2.0 \%+\mathrm{LN}$ $0.9 \%$.

의 E. coli $\mathrm{O} 157: \mathrm{H} 7$ 의 항균활성을 검정하였고, 실험 2에서는 두 가지 실험을 병행하였다. 먼 저, 저지방/저염 소시지에 락토페린을 단독 첨 가하여 제조하였고(Table 1, Exp. 2-1), 실험 2에 서는 락토페린과 젖산나트륨을 복합 첨가하여 제조하였다(Table 2, Exp. 2-2). 원료육은 하루 전에 도살한 돈육의 뒷다리 부위를 구입하였 다. 당일 구입한 돈육의 결체조직과 지방을 제 거하고 분쇄한 후, 시료로 사용할 때까지 동결 저장하여 보관하였다. 동결시킨 원료 돈육을 가공 전에 냉장실에서 약 하루 동안 해동 시킨 후 사용하였다.

\section{(2) 소시지의 제조}

저지방 및 유화형 소시지의 제조는 Chin 등 (2004)의 소시지 제조 방법에 따라 제조하였다. 소시지는 기존의 유화형 소시지 대조구(식염 $1.0 \%$ )와 저지방 세절 소시지(식염 $1.0 \%$; 지방대 체제 2.5\%, konjac flour : carrageenan : soy protein isolate $=1: 1: 3)$ 를 제조하였다(Table 3). 소시지는 지방이 제거된 돼지 뒷다리 부위를 1 차 만육기(Meat chopper, M-12s, 한국후지공업 주식회사, 보령시, 충청남도, 한국)로 만육한 후 세절기(Silent cutter, K-15, Talsa, EU)로 1차 세 절시 고기, 물, 식염, 인산염, 아질산염, 에르소
Table 3. Non-meat ingredients incorporated into low-fat/salt sausages

\begin{tabular}{ll}
\hline Non-meat ingredients & Amount(\%) \\
\hline \hline Fat replacers & $0-2.5$ \\
(konjac flour:carrageenan : & $(1: 1: 3)$ \\
$\quad$ soy protein isolate) & \\
Salt & 1 \\
Sugar & 1 \\
Corn syrup & 1 \\
Sodium tripolyphosphate & 0.3 \\
Non-fat dry milk & 1 \\
Maltodextrin & 1 \\
Hydrolyzed milk protein & 0.5 \\
Spices \#5 & 1 \\
Sodium erythorbate & 0.05 \\
Cure blend(NaNO ${ }_{2}$ ) & $0.25(150 \mathrm{ppm})$ \\
\hline
\end{tabular}

르빈산염 등과 2차 세절시 지방 또는 지방대체 제, 증량제, 향미제를 혼합한다. 혼합과 세절이 완료된 고기반죽을 진공포장 후 충진하였고, 충진된 고기 유화물은 훈연기(Nu-Vu, ES-13, Food System, Menominee, MI, USA)에서 훈연 
및 가열처리를 실시하였다. 내부온도가 $71.7^{\circ} \mathrm{C}$ 될 때, 냉각수로 냉각(내부온도 $40^{\circ} \mathrm{C}$ 이하)시켜 분석 전까지 $4^{\circ} \mathrm{C}$ 냉장고에 보관하였다.

(3) 소시지의 품질검사

1) $\mathrm{pH}$ 측정

고체용 $\mathrm{pH}$ meter(Mettler Toledo, MP120, schwerzenbach, switzerland)로 5회 측정하여 평 균값을 구하였다.

\section{2) 일반성분검사}

AOAC(1995) 방법에 따라 시료의 수분, 지방, 단백질성분을 분석하였다. 수분 함량은 Dry oven 법, 지방 함량은 Soxhlet 법, 단백질 함량 은 Kjeldahl 법으로 수행하였다.

\section{3) 가열감량}

가열 전 후의 무게 차에 의한 감량을 조사하 여 평가하였다.

가열감량(Cooking loss, \%) =

(가열 전 시료함량 - 가열 후 시료함량) $\times 100$

가열 전 시료 함량

4) 보수력(Water holding capacity, WHC)

보수력 측정을 위해 Jauregui 등(1981)의 방법 을 변형하여 시료 $1.5 \mathrm{~g}$ 을 4 등분한 Whatman \#3 여과지로 3 번 싼 뒤, 원심분리기로 3,000 $\mathrm{rpm}$ 에서 20 분간 원심 분리시킨다. 시료에서 여 과지로 유리된 수분 양으로 보수력을 환산하여 측정하였다.

유리수분(Expressible moisture, \%) =

$$
\frac{\text { 유리된 수분의 양 } \times 100}{\text { 시료의 무게 }}
$$

\section{5) 육색검사}

색도는 Chroma meter (CR-200, Minolta Corp., Ramsey, Japan)를 사용하여 소시지의 앞면을 4 번 측정하였고, 평균값을 Hunter L(lightness, 명 도), a(redness, 적색도), b(yellowness, 황색도) 값 으로 나타냈다.
6) 조직검사

제품의 물성은 Bourne (1972)의 방법으로 Instron universal testing machine (Model 3344, Canton, MA, USA)을 이용하여 Texture profile analysis (TPA)를 실시하여 경도(Hardness), 부서짐성(Fracturability), 탄력성(Springiness), 검성(Gumminess), 씹힘성 (Chewiness), 응집성(Cohesiveness)을 측정하였다. 실험조건은 $500 \mathrm{~N}$ 의 load cell에 cross speed는 300 $\mathrm{mm} / \mathrm{sec}$ 로 $75 \%$ 의 압착하였다.

\section{Escherichia coli $\mathrm{O} 157: \mathrm{H} 7$ 접종 및 락토 페린 처리}

본 실험에 사용한 락토페린(Lactoferrin, Tatua Nutritional, Morrinsville, New Zealand)은 평균분 자량이 $80 \mathrm{kDa}$ 이며, 철 포화도는 $14 \%$ 이고, $\mathrm{pH}$ 는 6.5 였다. 단백질 함량은 $97.4 \%$ 에 회분은 $1 \%$, 수분은 $0.7 \%$ 의 분말형태이다. 고체 배지에 배 양된 E. coli $\mathrm{O} 157: \mathrm{H7}$ 을 영양배지 $100 \mathrm{ml}$ 에 접 종하여 $37^{\circ} \mathrm{C}$ 에서 18 시간 진탕배양 $(150 \mathrm{rpm})$ 한 다음, 균 현탁액 $1 \mathrm{ml}$ 를 다시 새로운 영양배지 $(100 \mathrm{ml})$ 에 접종하고 18 시간 배양하여 균 현탁 액을 얻었다. 이 균 현탁액을 희석시켜 종균으 로 사용하였다. 항균효과를 측정하기 위해 처 리구 수에 따라 영양배지를 각각 $100 \mathrm{ml}$ 씩 만 들어 고압 멸균시켰다. 이 배지에 락토페린 농 도를 달리 첨가(실험1: $0,0.1,0.15,0.2,0.25 \%$; 실험2: $0,0.25,0.5,1 \%)$ 하여 제조하였다. 여기 에 10 배 희석시킨 종균 $1 \mathrm{ml}$ 를 접종시켜 진탕 배양기 $\left(150 \mathrm{rpm}, 37^{\circ} \mathrm{C}\right)$ 에서 배양하였다. 각각 0 , $3,6,9,12,24,36$ 시간동안 배양시킨 영양배지 에서 시료 $1 \mathrm{ml}$ 씩 취하여 분광광도계(UV1601, Shimazu, UV-Visible Spectrophotometer, Japan)로 $660 \mathrm{~nm}$ 에서 흡광도를 측정하였다.

\section{3. 저지방소시지의 미생물 검사(저장성)}

락토페린 $(0.05,0.1,0.2 \%)$ 을 단독 첨가 또는 락토페린과 젖산나트륨(2\%)의 복합 첨가 $(0.3$, $0.6,0.9 \%$ )에 의한 상승효과를 측정하기 위해서 저지방/저염 기능성 소시지에 E. coli O157:H7 을 일정 수준으로 접종한 후 선택배지는 Sorbitol 
MacConkey agar(Oxoid LTD, Basingstoke, Hampshire, England)와 supplement(Code SR172E)를 이용하 여 $37^{\circ} \mathrm{C}$ 에서 약 2 일간 배양 후 균락수를 측정 하였으며 그 결과를 colony forming unit(CFU)/g 으로 나타내었다.

\section{4. 통계처리}

본 실험은 3번 반복하였고 실험 결과는 SPSS $10.0(2000)$ 프로그램을 이용하여 일원배치분산 분석(One-way Analysis of Variance)으로 분석한 후, 유의차가 발견되었을 때, Duncan의 다중검 정법을 이용하여 대조구와의 유의차를 검정하 였다 $(\mathrm{p}<0.05)$.

\section{III. 결과 및 고찰}

락토페린의 항균활성을 평가하기 위하여 영 양배지에 첨가한 락토페린의 항 미생물 효과를 시간별로 확인하였고, 저지방/저염 소시지에 기 능성물질로 첨가하여 저장성을 보기 위해 저장 시간 별로 그 효과를 비교하였다.

\section{1. 락토페린의 항균활성 평가(실험 1)}

Fig. 1은 E. coli O157:H7의 성장을 흡광도로 확인한 결과로써, 락토페린 첨가 농도에 따라 균의 성장이 억제되는 시간이 달랐다. 특히, 락 토페린을 $0.1 \%$ 첨가한 경우는 대조구와 유사 한 성장을 보여 항균효과가 미미하였다. 반면 에 락토페린을 $0.2 \%$ 첨가한 배지는 $0.25 \%$ 와 유사한 항균효과를 보여주었다. $0.15 \%$ 는 대조 구와 $0.25 \%$ 의 중간 정도의 항균활성을 보여주 었다. 성장정체시간은 농도에 의존적으로 락토 페린 $0.25 \%$ 첨가배지는 24 시간, $0.2 \%$ 는 12 시간, $0.15 \%$ 는 4 시간 이었고, 반면에 락토페린 $0.1 \%$ 첨가배지는 항균효과가 거의 없는 것으로 평 가되었다. 또한 36 시간 이후에는 $0.25 \%$ 이하 의 농도의 경우는 모두 성장을 시작하였고, 반 면 $0.5 \%$ 이상의 농도는 120 시간까지 E. coli O157:H7의 성장을 지연시켰다. 이러한 결과는 Min 등(2005)이 $1 \%$ 의 peptone water에서 E. coli
O157:H7의 성장을 측정한 결과 락토페린의 농 도가 $0.5 \%$ 이상일 때 6일(144시간) 동안 성장 을 억제시켰다는 보고와 유사한 결과로써, 배 양하는 배지의 성분에 따라서 접종 균에 대한 성장억제효과가 다르며, 이는 E. coli O157:H7 에 대한 락토페린의 항균효과가 영양이 충분 한 환경에서는 초기성장을 저해하는 데 충분 하지 않다는 것을 시사한다. 또한 Dionysius 등(1993)은 장독소생성 대장균(enterotoxigenic E. coli O157:H7, ETEC)에 대해서 락토페린의 항균효과를 평가하는 연구에서 락토페린의 형 태에 따라 항균효과가 다르다고 평가하였다. 즉, $1 \mathrm{mg} / 1 \mathrm{ml}$ 의 농도의 락토페린이 아포(apo: 철포화도 $18 \%$ 이하)나 천연(native)의 형태일 경우 19 종 모두에서 항균효과를 나타낸 것과 달리 홀로(holo: 철 결합도 $30 \%$ 이상)상태 락 토페린은 항균효과를 나타내지 않았다고 보고 했다.

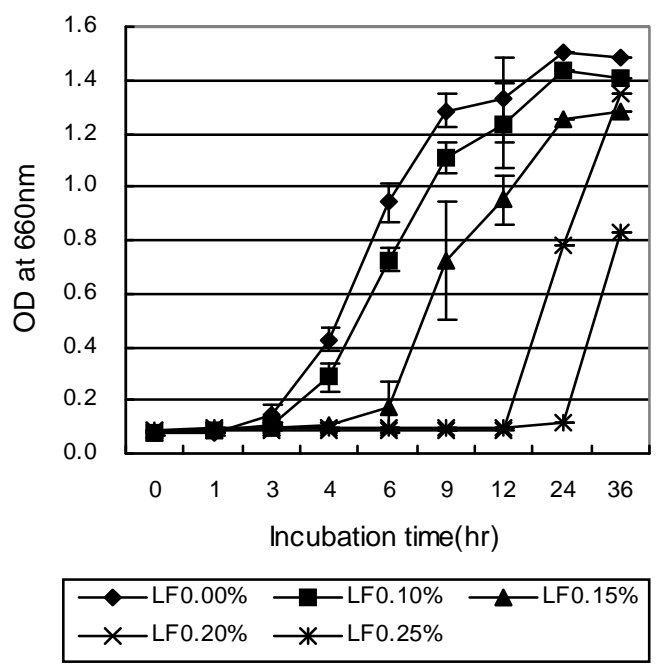

Fig. 1. Growth of E. coli O157:H7 in lactoferrinsupplemented nutrient medium(experiment 1-1).

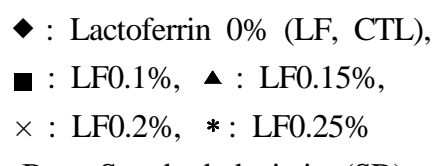

Bar: Standard deviation(SD) 


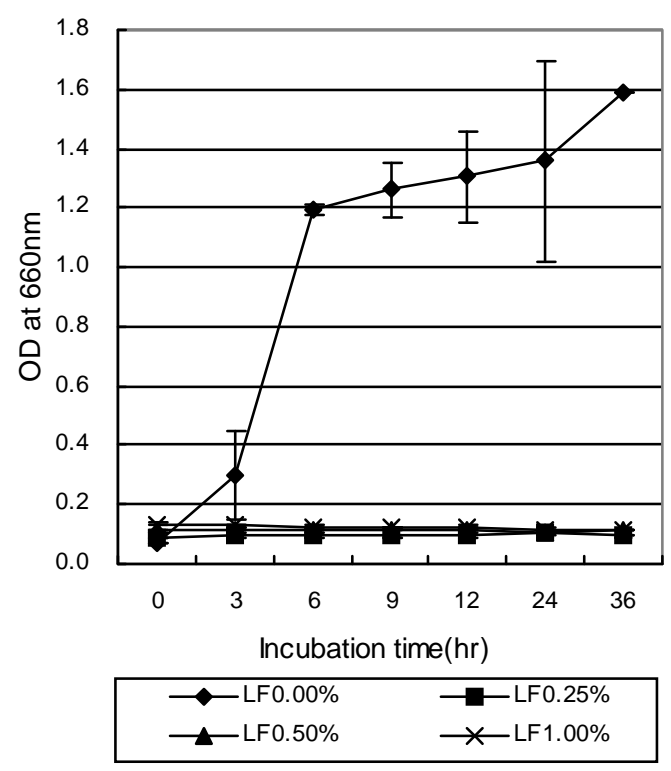

Fig. 2. Growth of $E$. coli $\mathrm{O} 157: \mathrm{H} 7$ in lactoferrinsupplemented nutrient medium (experiment 1-2).

- : Lactoferrin $0 \%$ (LF, CTL),

口 : LF0.25\%, $\triangle:$ LF0.5\%,

$x$ : LF1\%, Bar : Standard deviation(SD)
Fig. 2는 락토페린의 첨가량 $(0,0.25,0.5,1 \%)$ 을 높여 항균효과를 검사한 결과, 뚜렷한 항균 효과가 나타남을 보여주고 있다. 특히, 락토페 린의 농도에 상관없이 첨가하지 않은 대조구와 차이를 보이며 성장이 저해되었다. 이러한 결 과와 관련해서 Ellison 등(1988)은 락토페린에 의해 균의 성장이 억제되는 시간이 다르며, 그 람양성균의 세포외막을 손상시켜 성장을 저해 한다고 언급했다. 또한 Shin 등(1998)은 락토페 린 농도를 달리 $(0.5,1,2,3,4,6,8 \mathrm{mg} / \mathrm{ml})$ 하여 4종류의 임상에서 분리한 E. coli $\mathrm{O} 157: \mathrm{H7}$ 에 대 한 항균효과를 측정한 결과에서 $0.3 \%$ 농도가 항 균활성을 보였다고 보고하였다. 따라서 $0.25 \%$ 의 락토페린 첨가농도가 E. coli O157:H7 균의 성장 저해를 위한 최소 적정함량이라고 사료된다.

2. 락토페린을 단독 첨가한 저지방/저염 소 시지의 품질특성 및 저장성(실험 2-1)

(1) 락토페린 단독첨가 저지방/저염 소시지의 품질특성

Table 4는 락토페린을 첨가한 저지방/저염 소

Table 4. Product quality of low-fat/salt sausages with lactoferrin (experiment 2-1)

\begin{tabular}{lcccc}
\hline & LFC & LN1 & LN2 & LN3 \\
\hline \hline pH & 5.96 & 5.94 & 5.92 & 5.92 \\
Moisture (\%) & 77.3 & 77.0 & 76.7 & 76.8 \\
Fat (\%) & 1.40 & 1.66 & 1.50 & 1.46 \\
Protein (\%) & 15.9 & 15.4 & 15.9 & 15.4 \\
\hline Hunter L & 62.7 & 62.7 & 63.0 & 62.9 \\
\multicolumn{1}{c}{ a } & 19.2 & 20.4 & 19.0 & 21.8 \\
\multicolumn{1}{c}{ b } & 4.60 & 4.75 & 5.25 & 3.35 \\
\hline Expressible moisture (\%) & 24.5 & 26.7 & 26.2 & 24.1 \\
Cooking loss (\%) & 8.90 & 9.40 & 10.4 & 11.0 \\
\hline Hardness (g) & 4,642 & 4,591 & 4,080 & 4,962 \\
Springiness (cm) & 0.28 & 0.28 & 0.29 & 0.31 \\
Cohesiveness & 0.21 & 0.24 & 0.23 & 0.27 \\
Fracturability (g) & 3,291 & 3,299 & 3,414 & 3,246 \\
Gumminess & 798 & 956 & 911 & 880 \\
Chewiness & 194 & 254 & 264 & 244 \\
\hline
\end{tabular}

*Treatments : CTL, low-fat sausage without lactoferrin(LN); LN 0.05\%, LN 0.1\%, LN 0.2\%. 
시지의 품질특성을 실험 평가한 결과로써 $\mathrm{pH}$ 및 수분, 지방, 단백질 함량(\%)은 각각 5.92$5.94,76.7-77.3,1.40-1.66,15.4-15.9$ 로 나타 났고, 육색에서 명도, 적색도, 황색도는 각각 $62.7-63.0,19.0-21.8, \quad 3.35-5.25$ 로 측정되었 다. 기능성 검사결과에서는 유리수분이 24.126.7, 가열감량은 8.90-11.0 범위로 나타났다. 한편, 조직검사결과에서 경도, 탄력성, 응집성, 부서짐성, 검성 및 씹힘성은 각각 4,080-4,962 g, $0.28-0.31 \mathrm{~cm}, 0.21-0.27,3,291-3,414 \mathrm{~g}, 798-$ $956,194-264$ 로 평가되었으며, 모든 결과는 락 토페린 첨가량이 $0,0.05,0.1,0.2 \%$ 에 따른 유 의적인 차이를 보이지 않았다( $>>0.05)$. 이는 락 토페린의 첨가가 저지방/저염 소시지의 품질에 큰 영향을 주지 않는 것으로 보인다.

(2) 락토페린 단독첨가 저지방/저염 소시지의 저장성

E. coli $\mathrm{O} 157: \mathrm{H7}$ 을 $10^{4-5} \mathrm{cells} / \mathrm{g}$ 수준으로 소 시지에 접종하여 $30^{\circ} \mathrm{C}$ 저장실험을 수행한 결과 락토페린을 첨가한 처리구 $(0.1,0.15,0.2 \%)$ 의 항균효과가 확인되지 않아 저지방 소시지에 첨 가된 락토페린은 E. coli O157:H7에 대한 항균 효과가 나타나지 않았다(Fig. 3). 이는 액상배지 상태에서 확인한 항균활성능력이 식품에 적용 하였을 때는 효과가 나타나지 않은 결과로써, 락토페린의 항균활성기능이 열에 의해 소실될 수 있음을 시사하였다. 또한 소시지와 같은 복 합식품 내에서의 락토페린의 항균효과는 더욱 미 미하게 된 것으로 보이며, 이와 관련하여 Naidu (2002)는 분리 정제된 락토페린이 구조적 변 화, 열에 의한 변성 및 단백질 가수분해 등에 민감하다고 보고하였다. $\mathrm{pH}$, 칼슘이나 인산 그 리고 철 이온의 포화 및 적합하지 못한 citrate/ bicarbonate 비율과 관련된 이온변화와 같은 조 건들도 락토페린의 항균활성을 현저하게 감소 시킬 수 있다고 언급하였다. 한편, Abe 등(1991) 은 락토페린이 첨가되는 $\mathrm{pH}$ 조건이 락토페린의 항균활성에 영향을 주는 요인이라고 보고했으 며, 이는 열에 의한 변성 정도가 $\mathrm{pH}$ 조건에 따 라 다르며, $\mathrm{pH}$ 가 4.0 에서 5.0 과 같이 낮은 산 성조건에서는 $80^{\circ} \mathrm{C}$ 로 5 분간 가열처리한 경우에
락토페린의 철이온 결합능력의 상실은 없었고, $100{ }^{\circ} \mathrm{C}$ 에서 5 분간 가열한 후에도 $85 \%$ 의 철이온 결합능력을 유지하였다고 보고하였다. 심지어 $120^{\circ} \mathrm{C}$ 로 가열처리한 후에도 4.0 이하의 $\mathrm{pH}$ 조 건에서는 가열처리하지 않은 락토페린과 항균 활성이 동등하게 평가되었다. 이러한 결과는 소시지의 $\mathrm{pH}$ 가 6.0 범위에 해당하므로 첨가한 락토페린의 열에 대한 안정성이 저하될 수 있 음을 시사하였다. 그러므로 락토페린을 제조에 직접 첨가하기 보다는 열에 의한 변성을 방지 하기 위하여 케이싱에 필름형태로 도포하면 오 염된 미생물을 사멸시키는데 효과적으로 사용 될 수 있을 것으로 사료된다.

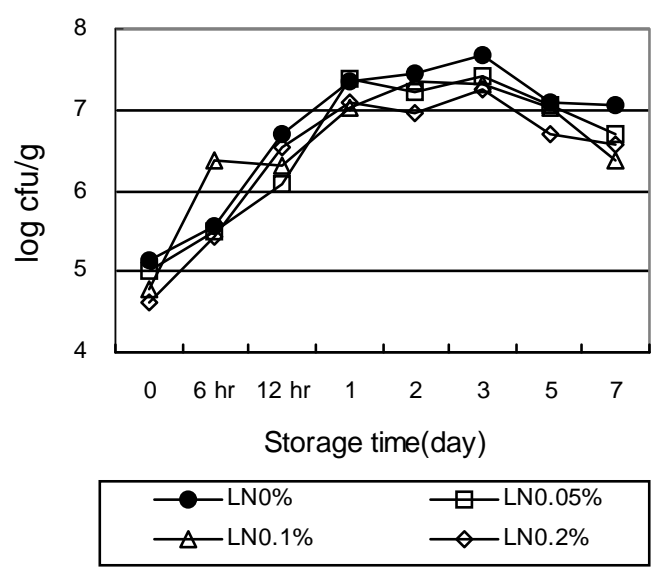

Fig. 3. Microbial changes of E. coli O157:H7 (log cfu/g) in low-fat/salt sausages as affected by levels of lactoferrin inoculated at $30^{\circ} \mathrm{C}$.

3. 락토페린과 젖산나트륨 복합첨가 저지방/ 저염 소시지의 품질특성 및 저장성(실험 2-2)

(1) 락토페린과 젖산나트륨 복합첨가 저지방/ 저염 소시지의 품질특성

Table 5는 유화형소시지 및 저지방/저염 소시 지의 품질특성을 실험 평가한 결과로써 $\mathrm{pH}$ 및 일반성분은 각각 $5.70-5.92,59.8-76.7 \%, 1.27$ $-20.5 \%, 13.4-14.7 \%$ 로 나타났고, 저지방/저염 소시지 간의 젖산나트륨 또는 락토페린과 젖산 나트륨 복합첨가에 따른 $\mathrm{pH}$ 및 일반성분은 유 
Table 5. Product quality of low-fat/salt sausages with lactoferrin and sodium lactate (experiment 2-2)

\begin{tabular}{lcccccc}
\hline & RFC & LFC & SLC & LS1 & LS2 & LS3 \\
\hline \hline pH & 5.92 & 5.70 & 5.85 & 5.83 & 5.90 & 5.85 \\
Moisture (\%) & $59.8^{\mathrm{b}}$ & $76.7^{\mathrm{a}}$ & $75.8^{\mathrm{a}}$ & $75.0^{\mathrm{a}}$ & $75.6^{\mathrm{a}}$ & $74.8^{\mathrm{a}}$ \\
Fat (\%) & $20.5^{\mathrm{a}}$ & $1.42^{\mathrm{b}}$ & $1.66^{\mathrm{b}}$ & $1.71^{\mathrm{b}}$ & $1.27^{\mathrm{b}}$ & $1.46^{\mathrm{b}}$ \\
Protein (\%) & 14.7 & 14.1 & 13.7 & 13.5 & 13.4 & 14.1 \\
\hline Hunter L & $72.3^{\mathrm{a}}$ & $67.2^{\mathrm{b}}$ & $67.0^{\mathrm{b}}$ & $66.7^{\mathrm{b}}$ & $67.4^{\mathrm{b}}$ & $67.6^{\mathrm{b}}$ \\
\multicolumn{1}{c}{$\mathrm{a}$} & 10.7 & 10.0 & 10.5 & 10.3 & 9.80 & 10.1 \\
\hline b & 7.60 & 6.90 & 7.50 & 7.70 & 7.40 & 7.50 \\
\hline Expressible moisture (\%) & $16.0^{\mathrm{b}}$ & $35.3^{\mathrm{a}}$ & $33.2^{\mathrm{a}}$ & $32.2^{\mathrm{a}}$ & $27.2^{\mathrm{a}}$ & $30.3^{\mathrm{a}}$ \\
\hline Cooking loss (\%) & 6.10 & 8.50 & 6.70 & 6.90 & 5.80 & 6.10 \\
\hline Hardness (g) & 5,273 & 4,315 & 4,373 & 4,365 & 5,828 & 5,155 \\
Springiness (cm) & 0.32 & 0.25 & 0.29 & 0.27 & 0.30 & 0.31 \\
Cohesiveness & 0.25 & 0.21 & 0.24 & 0.25 & 0.24 & 0.26 \\
Fracturability (g) & 3,122 & 3,241 & 2,974 & 2,975 & 3,967 & 3,449 \\
\hline Gumminess & 1,357 & 897 & 1,057 & 1,068 & 1,442 & 1,271 \\
\hline
\end{tabular}

*Treatments: RFC, regular-fat control(fat 20\%, salt 1.0\%); LFC, low-fat control(salt 1.0\%); LS0= sodium lactate(SL) $2.0 \%$ only; LS1= SL $2.0 \%$ + lactoferrin(LN) $0.3 \%$; LS2= SL $2.0 \%+\mathrm{LN} 0.6 \%$; LS3= SL $2.0 \%+\mathrm{LN} 0.9 \%$.

a,b Means having same superscript within same column are not different( $\mathrm{p}>0.05)$.

의적인 차이가 없었으나, 유화형 대조구는 수 분 및 지방성분에서 저지방/저염 소시지 전 처 리구와 유의적인 차이를 보였다 $(\mathrm{p}<0.05)$. 이는 제조 배합비상 유화형대조구의 높은 지방첨가 량과 낮은 수분첨가에 따른 것으로 평가된다. 육색도는 명도, 적색도, 황색도는 각각 66.7$72.3,9.80-10.7,6.90-7.70$ 로 측정되었고, 적색 도와 황색도는 처리구에 따른 유의차가 없었으 나(p>0.05), 명도는 유화형 대조구와 저지방/저 염 소시지 전 처리구와 유의적인 차이를 보이 며 높게 나타났다 $(\mathrm{p}<0.05)$. 이러한 결과 또한 유화형대조구의 높은 지방첨가량에 기인한 것 으로 보인다. 한편, 기능성 검사결과에서는 유 리수분이 $16.0-35.3 \%$, 가열감량은 $5.80-8.50 \%$
범위로 확인되었다. 가열감량은 전 처리구에서 유화형 대조구와 유의적인 차이를 보이지 않았 으며(p>0.05), 이는 저지방/저염소시지에 첨가된 지방대체제의 가열에 의한 수분의 유리를 완충 하는 효과에 기인한 것으로 평가된다. 반면에, 보수력 측정결과에서는 저지방/저염 소시지가 유화형 대조구에 비해 유의적으로 더 낮은 보 수력을 보였다 $(\mathrm{p}<0.05)$. 이는 Choi와 Chin(2002) 이 보고한 저지방소시지에 첨가한 지방대체제 의 효과로 유화형 대조구와 보수력에서 유의적 인 차이를 보이지 않았다는 결과와 상이한 것 으로써, 이러한 결과는 제조한 저지방소시지의 식염첨가량의 차이에 기인한 것으로 보이며, 본 연구는 $1.0 \%$ 식염을 첨가한 것과 달리 Choi 와 
Chin(2002)이 제조한 저지방소시지에는 $0.5 \%$ 높 은 $1.5 \%$ 수준으로 식염이 첨가되었다. 한편, 조 직검사결과에서 경도, 탄력성, 응집성, 부서짐 성, 검성 및 씹힘성은 각각 $4,080-4,962 \mathrm{~g}, 0.28$ $-0.31 \mathrm{~cm}, 0.21-0.27,3,291-3,414 \mathrm{~g}, 798-956$, 194-264로 평가되었으며, 이는 Choi와 Chin (2002)이 보고한 저지방 소시지 제조시 첨가한 지방대체제의 효과로 유화형소시지와 유사한 조직특성을 보였다는 결과와 유사하였다. 이렇 게 유화형 대조구와 저지방처리구들 간에는 제 품 특성상 몇몇의 차이를 보인 것과 달리 락토 페린 첨가량의 증가나 젖산나트륨과의 복합첨 가를 통한 저지방/저염 소시지 처리구간의 품 질에 있어서 유의적인 차이는 나타나지 않았다 $(\mathrm{p}>0.05)$. 즉, 첨가한 락토페린과 젖산나트름의 첨가에 의한 제품 특성상의 변화는 크지 않다 고 평가할 수 있다.

\section{(2) 락토페린과 젖산나트륨 복합첨가 저지방/ 저염 소시지의 저장성}

실험 2-1에서 락토페린 함량에 따른 항균효 과가 나타나지 않아서 락토페린의 첨가량 $(0.3$, $0.6,0.9 \%)$ 을 높여서 첨가하였고, 또한 락토페린 을 다른 항균물질과 복합 첨가할 때 상승효과 가 있다는 Branen과 Davidson(2004)의 보고에 따라 이미 천연보존료로써 그 기능이 확인된 젖산나트륨 용액(60\%)을 복합 첨가하여 항균효 과를 평가하였다(Chin과 Choi, 2005; Choi와 Chin, 2003; Choi 등, 2003). $4{ }^{\circ} \mathrm{C}$ 에서 8주간 냉 장저장 중에 $10^{3}$ cells/g 수준으로 접종한 E. coli O157:H7의 경우 젖산나트륨을 단독으로 첨가 할 경우 4주 이후에 $10^{2}$ cells/g 으로 나타났으나 락토페린을 $0.3-0.6 \%$ 복합으로 첨가할 경우, 오히려 항균효과가 낮아졌다(Fig. 4). 즉, 첨가 한 락토페린이 젖산나트륨과 함께 항균효과의 상승작용을 보이기보다 오히려 미생물의 성장 을 촉진시키는 작용을 한 것으로 나타났다. 이 러한 결과는 Al-Nabulsi와 Holley(2006)가 보고 한 젖산나트륨과 락토페린의 복합첨가는 $E$. coli O157:H7에 대한 항균효과가 상승한다는 모델연구와 상반된 결과로써 소시지와 같은 살 균 제품의 경우 내부온도가 $71^{\circ} \mathrm{C}$ 가 될 때까지
가열처리를 하기 때문에 단백질인 락토페린은 열에 의한 변성이 될 수 있고, 이로 인한 항균 활성이 저해될 수 있다고 평가된다. 이에 대하 여 Riiegg 등(1977)은 락토페린의 열변성에 대 한 연구에서 $\mathrm{pH} 6.6$ 에서는 65 에서 $69^{\circ} \mathrm{C}$ 범위의 열처리 시에 단백질의 변성을 보였다고 보고하 였으며, Ford 등(1977)은 인유 중의 락토페린의 열변성에 대한 연구에서 $\mathrm{pH} 6.6$ 과 $70^{\circ} \mathrm{C}$ 조건에 서 15 분간 열처리한 경우 인유 내에 존재하는 락토페린이 완전히 파괴됨을 보고하였다. 이러 한 결과는 소시지의 살균온도가 충분히 락토페 린의 변성을 초래할 수 있음을 시사한다. Abe 등(1991)은 락토페린을 $60 \sim 70{ }^{\circ} \mathrm{C}$ 수준으로 열처 리할 경우에 불안정화 되어, 응집현상과 용해 도의 저하가 관찰된다고 보고하였다. 항균활성 효과는 락토페린에 결합된 철 이온의 포화도가 낮을수록 좋으나 철 이온 포화도가 낮은 락토 페린은 포화도가 높은 락토페린보다 열안정성 이 낮다고 Sanchez 등(1992)은 보고하였다. 따 라서 본 연구에서 사용된 락토페린의 철 이온 포화도는 $14 \%$ 정도로 철 이온의 결합정도가 낮아 배지에서 확인한 항균효과는 현저했으나,

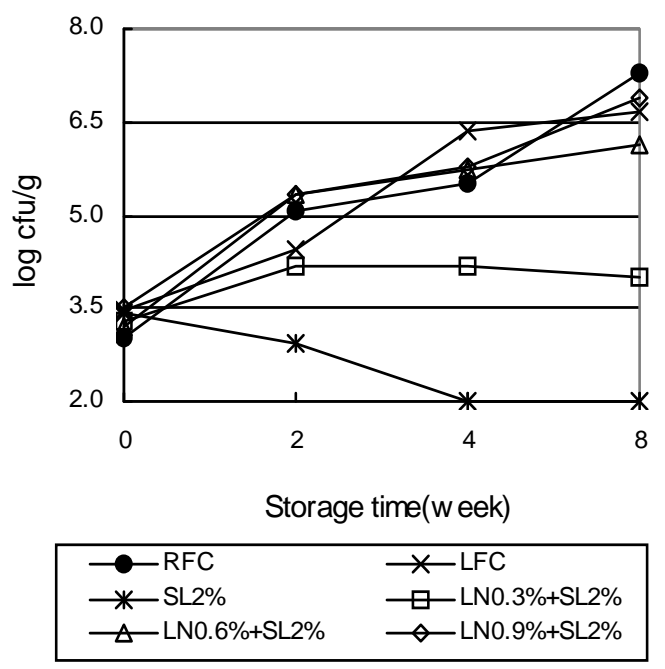

Fig. 4. Microbial changes of E. coli O157:H7 (log cfu/g) in low-fat/salt sausages as affected by sodium lactate in combination with various levels of lactoferrin stored at $4^{\circ} \mathrm{C}$. 
가열처리를 한 소시지에 대한 항균활성이 미미 한 것으로 평가되었다. 그러므로 락토페린의 열 변성을 최소화하는 조건을 유지하여 식육제 품을 제조할 경우에는 열변성에 의한 항균활성 효과의 저해를 막을 수 있을 것으로 사료된다. 한편, 생소시지와 같은 비 가열 식육제품이나 첨가물이 많이 첨가되지 않는 식육제품에 락토 페린을 첨가하여 제조할 경우에는 항균효과가 부여될 것으로 사료된다(Naidu, 2002). $\mathrm{pH}$ 가 4 에서 5정도인 발효 육제품이나 가열 처리 후 가공되는 pate와 같은 육제품에 첨가할 경우에 는 항균활성을 함유할 것으로 보여 제품의 저 장성 증진에 기여할 것으로 예상된다. 또한 락 토페린의 항균효과를 상승시키기 위하여 이미 언급한 바와 같이 가열 후 케이싱에 필름 형태 로 코팅하는 것도 바람직할 것으로 평가된다. 그 밖에 락토페린이 첨가된 분유나 기능성 식 품의 경우 가열에 의해 저해될 수 있는 항균효 과 외에 면역력 증진 및 여러 기능성이 확인되 고 있어, 락토페린 첨가를 통한 기능성 식육제 품의 제조는 앞으로 가능할 것으로 판단된다.

\section{IV. 요 약}

기능성 식육제품을 제조하기 위해 첨가한 락 토페린의 항균활성을 평가하기 위해 Escherichia coli O157:H7을 일정 수준으로 접종하고 락토페 린을 0 에서 $1 \%$ 로 달리 첨가한 결과, 농도에 의 존적으로 항균활성을 나타냈으며, 특히 $0.25 \%$ 이상의 농도에서는 접종균에 대한 뚜렷한 항균 효과를 나타냈다. 이러한 결과를 근거로 소시지 의 저장성 증진을 위해 락토페린을 첨가하여 제 조하였으나 저장성 실험 결과에서는 항균효과 가 확인되지 않았다. 또한 젖산나트륨을 $2 \%$ 첨 가하고 락토페린을 0.3 에서 $0.9 \%$ 로 복합 첨가하 여 $4^{\circ} \mathrm{C}$ 저장 중에 접종한 E. coli O157:H7에 대 한 항균활성을 측정한 결과에서는, 젖산나트륨 $2 \%$ 단독 첨가구는 4 주 이후 접종균의 생장이 억제되었으나 젖산나트륨과 락토페린을 복합첨 가한 첨가구는 락토페린의 농도가 증가할수록 저장기간 동안 접종균의 성장으로 항균효과가 오히려 감소하였다. 따라서 모델결과에서 보여
준 항균효과는 실질적인 식육제품실험에서는 나타나지 않았으며, 이러한 결과는 제조 및 가 열 중에 락토페린의 변성과 소시지 제조에 첨가 되는 복합첨가물들의 영향으로 첨가된 락토페 린의 항균활성이 저해된 것으로 판단된다. 차후 의 연구로 락토페린의 항균활성을 높이기 위하 여 케이싱의 내면에 필름으로 처리하는 방법으 로 항균활성효과를 연구하는 것이 필요할 것으 로 사료된다.

$$
\mathrm{V} \text {. 사 사 }
$$

본 연구는 한국과학재단 목적기초연구(R082003-000-10568-0)지원으로 수행한 결과로서 연 구비 지원에 감사드립니다.

\section{VI. 인 용 문 헌}

1. Abe, H., Saito, H., Miyakawa, H., Tamura, Y., Shimamura, S., Nagao, E. and Tomita, M. 1991. Heat stability of bovine lactoferrin at acidic $\mathrm{pH}$. J. Dairy Sci. 74:65-71.

2. Al-Nabulsi, A. A. and Holley, R. A. 2006. Enhancing the antimicrobial effects of bovine lactoferrin against Escherichia coli O157:H7 by cation chelation, $\mathrm{NaCl}$ and temperature. J. Appl. Microbiol. 100:244-255.

3. AOAC. 1995. Official Methods of Analysis. Association of official analysis chemists (15th ed). Washington, DC.

4. Benkeblia, N. 2004. Antimicrobial activity of essential oil extracts of various onions(Allium cepa) and garlic (Allium sativum). Lebensm.-Wiss. u.-Technol. 37:263-268.

5. Bourne, M. C. 1978. Texture profile analysis. Food Technol. 32(7):62-66, 72.

6. Branen, J. K. and Davidson, P. M. 2004. Enhancement of nisin, lysozyme, and monolaurin antimicrobial activities by ethylene diameinetetraacetic acid and lactoferrin. International J. Food Microbiol. 90:63-74.

7. Chin, K. B. and Choi, S. H. 2005. Evaluation of 
sodium lactate combined with chitosans of various molecular weights and lac pigment for the extension of shelf-life and color development of low-fat sausages during refrigerated storage. Food Sci. Biotechnol. 14(2):275-279.

8. Chin, K. B., Lee, H. L., Kook, S. H., Yoo, S. S. and Chun, S. S. 2004. Evaluation of various combinations of pork lean and water added on the physicochemical, textural and sensory characteristics of low-fat sausages. Food Sci. Biotechnol. 13(4): 481-485.

9. Choi, S. H. and Chin, K. B. 2002. Development of low-fat comminuted sausage manufactured with various fat replacers similar textural characteristic those with a regular fat counterpart. Korean J. Food Sci. Technol. 34(4):577-582.

10. Choi, S. H. and Chin, K. B. 2003. Evaluation of sodium lactate as a replacement for conventional chemical preservatives in comminuted sausages inoculated with Listeria monocytogenes. Meat Sci. 65:531-537.

11. Choi, S. H., Kim, K. H., Eun, J. B. and Chin, K. B. 2003. Growth suppression of inoculated Listeria monocytogenes and physicochemical and textural properties of low-fat sausages as affected by sodium lactate and a fat replacer. J. Food Sci. 68(8):2542-2546.

12. Cvetnic, Z. and Vladimir-Knezevic, S. 2004. Antimicrobial activity of grapefruit seed and pulp ethanolic extract. Acta Pharm. 54:243-250.

13. Darmadji, P. and Izumimoto, M. 1994. Effect of chitosan in meat preservation. Meat Sci. 38:243254.

14. De Wit, J. C. and Rombouts, F. M. 1990. Antimicrobial activity of sodium lactate. Food Microbiol. 7(2):113-120.

15. Dionysius, D. A., Grieve, P. A. and Milne, J. M. 1993. Forms of lactoferrin: their antibacterial effect on enterotoxigenic Escherichia coli. J. Dairy Sci. 76:2597-2606.

16. DMV. 2001. Lactoferrin. DMV International, 14 June.
17. Ellison III, R. T. and LaForce, F. M. 1988. Damage of the outer membrane of enteric gramnegative bacteria by lactoferrin and transferrin. Infect. Immun. 56:2774-2781.

18. Farnaud, S. and Evans, R. W. 2003. Lactoferrin-a multifuctional protein with antimicrobial properties. Molecular Immunol. 40:395-405.

19. Ford, J. E., Law, B. A., Marshall, V. M. E. and Reiter, B. 1977. Influence of the heat treatment of human milk on some of its protective constituents. J. Pediatr. 90:29-35.

20. Jauregui, C. A., Regenstein, J. N. and Baker, R. C. 1981. A simple centrifugal method for measuring expressible moisture, a water binding property of muscle foods. J. Food Sci. 46:1271- 1273.

21. Jo, G. H., Jin, Y, L., Chin, K. B. and Park, R. D. 2002. Effect of chitosan on the growth of food-poisoning bacteria. J. Chitin Chitosan 7(4): 219-224.

22. Jovani, M., Barbera, R. and Farre, R. 2003. Effect if lactoferin addition on the dialysability of iron from infant formulas. J. Trace Elem. Med. Biol. 17(2):139-142.

23. Kim, J. W., Matsler, P. L., Wang, H. and Slavik, M. F. 1996. Grapefruit seed extract (DF-100) treatment of poultry to reduce attached salmonella. J. Fd. Hyg. Safety 11(1):7-10.

24. Kumari J., Swain, T., Sahoo, P. K. 2003. Dietary bovine lactoferrin induces changes in immunity level and disease resisteance in Asian catfish Clarias batrachus. Vet. Immunol. Immunopathol. 94:1-9.

25. Lemay, M-J., Choquette, J., Delaquis, P. J., Gariepy, C., Rodrigue, N. and Saucier, L. 2002. International J. Food Microbiol. 78:217-226.

26. Min, S. C., Harris, L. J. and Krochta, J. M. 2005. Antimicrobial effects of lactoferrin, lysozyme, and the lactoperoxidase system and edible whey protein films incorporating the lactoperoxidase system against Salmonella enterica and E. coli O157:H7. J. Food Sci. 70(7):332-338.

27. Naidu, A. S. 2002. Activated lactoferrin-a new 
approach to meat safety. Food Technol. 56(3): 40-45.

28. Ransom, J. and Belk, K. 2003. Susceptibility of Escherichia coli O157:H7, Salmonella typhimurium, and Listeria monocytogenes inoculated onto beef tissues, steaks and RTE products, to lactic acid, lactoferrin and activated lactoferrin. project summary. National cattlemen's beef association center for research and knowledge management. pp. 1-3.

29. Riiegg, M., Moor, U. and Blanc, B. 1977. A calorimetric study of the thermal denaturation of whey proteins in simulated milk ultrafiltrate. J. Dairy Res. 44:509-520.

30. Sallam, K. I., Ishioroshi, M. and Samejima, K. 2004. Antioxidant and antimicrobial effects of garlic in chicken sausage. Lebensm.-Wiss. u.Technol. 37:849-855.
31. Sanchez, L., Peiro, J. M., Castillo, H., Perez, M. D., Ena, J. M. and Calvo, M. 1992. Kinetic parameters for denaturation of bovine milk lactoferrin. J. Food Sci. 57(4):873-879.

32. Shin, K., Yamauchi, K., Teraguchi, S., Hayasawa, H., Tomita, M., Otsuka, Y. and Yamazaki, S. 1998. Antimicrobial activity of bovine lactoferrin and its peptides against enterohaemorrhagic Escherichia coli O157:H7. Letters in Applied Microbiol. 26:407411.

33. Qin, C., Li, H., Xiao, Q., Liu, Y., Zhu, J. and Du, Y. 2006. Water solubility of chitosan and its antimicrobial activity. Carbohydrate Polymers 63: 367-374.

(접수일자 : 2006. 7. 3. / 채택일자 : 2006. 8. 16.) 